\title{
Analisis Faktor-faktor yang Mempengaruhi Relasi Kuasa Pelaku Kekerasan dalam Rumah Tangga (KDRT)
}

\author{
Melsi Syawitri ${ }^{1} \&$ Afdal $^{*}$ \\ ${ }^{12}$ Universitas Negeri Padang \\ *Corresponding Author: afdal@konselor.org
}

Published Online 9 Agustus 2020

(C) IICET Journal Publication, 2020

\begin{abstract}
Cases of violence in Indonesia, especially against women in the household, have increased so that it is considered quite alarming. Domestic violence perpetrated by the perpetrator, in this case the husband, is motivated by power relations in the household. This research aims to analyze the factors that influence the power relations of domestic violence (KDRT).The method used in this research is a descriptive qualitative approach with the research subject, namely a criminal case of domestic violence. The data collection techniques used were observation, interviews and document analysis. The data analysis technique is carried out through three activities, including data reduction, data presentation, and drawing conclusions. The result of the research shows that there is a real power relation of violence in household; (1) gender perception bias, based on the results found that there is an understanding that is still gender biased in the perceptions of domestic violence perpetrators, (2) aggressive personality is higher in men. This is related to the social roles inherent in men and women. So that with a reasonable view that aggressive is higher in men, causing the perpetrator to feel for verbal and physical aggression. The perpetrator who has an aggressive personality causes him to become irritable by participating in verbal and physical aggression. (3) The perpetrator who has an antisocial personality is related to the tendency to carry out criminal activities such as domestic violence without being followed by feelings related to the act of action. The results of the research are expected to help community institutions to pay more attention to the conditions of domestic violence perpetrators and especially counselors to be able to provide interventions in the form of counseling programs to perpetrators as preventive and handling measures in order to break the chain of domestic violence. It is also hoped that the counselor can educate the perpetrators to change their mindset and behavior and help them in the future to be able to integrate with society.
\end{abstract}

Keyword: Power Relations, Perpetrators of Domestic Violence

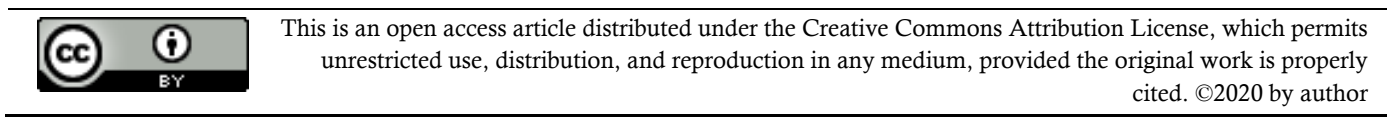

\section{PENDAHULUAN}

Kekerasan dalam rumah tangga (KDRT) umumnya dilakukan oleh orang yang paling dekat dengan korban dan suami merupakan orang yang dominan menjadi pelaku kekerasan terhadap istri. Kekerasan dalam rumah tangga dapat terjadi karena belum tersentuhnya kesadaran keluarga dalam meningkatkan kualitas diri melalui penerapan pemahaman fungsi keluarga (Afdal, 2015; Muljono, 2015). World Health Organization (WHO) melaporkan bahwa hampir sepertiga (30\%) dari semua perempuan telah mengalami kekerasan fisik atau seksual oleh pasangan intim mereka. Perkiraan dari jumlah keseluruhan kekerasan tersebut berkisar dari 23,2\% di negaranegara berpenghasilan tinggi, 24,6\% di wilayah Pasifik Barat, 37\% di wilayah Mediterania Timur, dan 37,7\% di wilayah Asia Tenggara (WHO, 2013). Sementara itu di Indonesia, catatan tahunan Komisi Nasional Perempuan Indonesia memaparkan bahwa kekerasan yang terjadi dalam ranah 
KDRT/ personal merupakan kasus yang paling beresiko terhadap perempuan. Tahun 2018, kasus kekerasan terhadap perempuan dalam ranah KDRT/ personal tercatat sebanyak 9.606 kasus dan tahun 2019 tercatat sebanyak 9.637 kasus, yang terdiri dari berbagai bentuk kekerasan, meliputi kekerasan terhadap istri (KTI), kekerasan dalam pacaran (KDP), kekerasan terhadap anak perempuan (KTAP), kekerasan yang dilakukan oleh mantan suami dan mantan pacar, kekerasan yang terjadi pada pekerja rumah tangga, dan ranah personal lainnya (Komnas Perempuan, 2019).

Kekerasan tentunya memiliki dampak yang merugikan bagi korban KDRT terutama istri. Kekerasan untuk waktu yang lama memiliki konsekuensi yang serius bagi korban baik dari segi fisik dan psikologis (Rakovec-Felser, 2014). Korban akan mengalami kurangnya rasa percaya diri yang menghambat kemampuan untuk melakukan kegiatan sosial, gangguan kesehatan serta mengurangi otonomi pada bidang ekonomi, politik ataupun sosial budaya (Pasalbessy, 2010). Maka dapat dikatakan bahwa dampaknya tidak hanya dirasakan pada diri korban tetapi juga terhadap perkembangannya dengan lingkungan sekitarnya (Zikra, 2019). Korban KDRT juga sering menunjukkan situasi kesehatan mental yang terkait dengan riwayat trauma terhadap kekerasan dalam keluarga mereka (Garcia \& Schneider, 2017). Adapun kekerasan yang diterima korban dalam rumah tangga ini umumnya juga tidak hanya satu jenis, dimana kekerasan fisik yang diterima biasanya juga diikuti oleh kekerasan psikis, atau kekerasan fisik bersamaan dengan kekerasan ekonomi, atau keempat bentuk kekerasan dapat menimpa korban sehingga memunculkan penderitaan yang berlipat ganda (Mufidah, 2008).

Faktor-faktor yang berhubungan dengan tindakan kekerasan yang dilakukan pelaku KDRT diantaranya meliputi faktor internal seperti karakteristik kepribadian (Ybarra, Wilkens, \& Lieberman, 2007) serta agresif (Asnawi, 2011; Soeroso, 2010) dan faktor eksternal seperti bias gender (Manumpahi, Goni, \& Pongoh, 2016), keuangan (Gage \& Hutchinson, 2006), relasi kuasa (Asnawi, 2011), transmisi antargenerasi (Rakovec-Felser, 2014), pemahaman agama yang salah (Sofiani, 2008), pemahaman ideologi harmoni (Harnoko, 2010), kontrol diri yang rendah (Asmarany, 2007) serta mengkonsumsi minuman beralkohol (Vyas \& Jansen, 2018). Adapun suami sebagai pelaku KDRT umumnya melakukan kekerasan dengan dilatarbelakangi oleh faktor relasi kuasa yang tidak setara antara suami-istri (Vyas \& Jansen, 2018). Relasi kuasa merupakan relasi yang bersifat hierarkis, ketidaksetaraan atau ketergantungan status sosial, budaya, pengetahuan dan/atau ekonomi yang menimbulkan kekuasaan satu pihak terhadap pihak lainnya dalam konteks relasi antar gender sehingga merugikan pihak yang memiliki posisi lebih rendah (Peraturan Mahkamah Agung Republik Indonesia Nomor 3 Tahun 2017 tentang pedoman mengadili perkara perempuan berhadapan dengan hukum, 2017)

Relasi kuasa suami cenderung memiliki tingkat konflik, kontrol, dan kekerasan yang tinggi terhadap istri (Antai, 2011). Suami dengan kekuasaannya menekan orang-orang yang berada di dalam lingkungan rumah tangganya (Manumpahi et al., 2016), sehingga relasi kuasa antara suami dan istri memiliki dampak yang tentunya tidak menyenangkan bagi istri. Suami yang merasa berkuasa menyebabkan kurangnya rasa menghargai dan bersikap semena-mena terhadap istri (Ciciek, 2005). Istri dianggap sebagai orang yang memenuhi keinginan suami, sehingga istri yang bersalah dan tidak patuh pada suami berhak untuk dipukul oleh suami karena kodratnya istri harus mematuhi suami (Harnoko, 2010)(Sari \& Afdal, 2020). Maka, dalam hal ini istri yang mendapatkan porsi kekuasan paling kecil mengakibatkannya rentan menjadi korban kekerasan dalam kehidupan rumah tangga (KDRT).

Lapas klas II A Padang merupakan salah satu lembaga tempat melakukan pembinaan terhadap narapidana dan tahanan di kota Padang. Berdasarkan data awal ditemukan bahwa warga binaan terkait kasus KDRT di Lapas klas II A Padang adalah narapidana yang melakukan kekerasan fisik terhadap istri. Kekerasan dilatarbelakangi oleh permasalahan verbal yang tidak terselesaikan hingga pada tindakan aniaya terhadap istri. Adanya permasalahan tersebut, diperlukan penelitian untuk menganalisis faktor-faktor yang mempengaruhi relasi kuasa pelaku KDRT.

Faktor yang mempengaruhi relasi kuasa pelaku kekerasan dalam rumah tangga umumnya adalah persepsi bias gender. Laki-laki dipandang mempunyai peluang lebih besar dalam melakukan kekerasan terhadap perempuan, terlihat pada beberapa penelitian yang mengungkap bahwa laki-laki harus lebih tinggi statusnya dibandingkan status seorang perempuan yang merupakan pasangannya (Asmarany, 2007), suami memiliki kedudukan yang lebih tinggi dari istri dimana suami mempunyai kekuasaan penuh dalam menjalankan rumah tangga (Chrysos, Taft, King, \& King, 2005). Selain itu, penggambaran bahwa laki-laki dianggap lebih berkuasa dan kuat mengakibatkannya lebih agresif sehingga bisa menyebabkan kekerasan pada perempuan yang dilakukan dalam rumah tangga (Witte, Schroeder, \& Lohr, 2006). Adapun relasi kuasa pelaku 
kekerasan dalam rumah tangga juga dipengaruhi oleh ketidakmandirian ekonomi istri. Kekuasaan pelaku yang lebih tinggi daripada korban dipengaruhi oleh penguasaan pelaku dalam sistem ekonomi. Karena suami menghabiskan waktu disektor yang menghasilkan uang sementara istri mengurusi rumah tangga dan mengasuh anak. Hal ini membuat pekerjaan suami dipandang lebih bernilai. Pekerjaan rumah tangga tidak dianggap penting karena tidak mempunyai nilai uang (Asnawi, 2011). Hal ini mendorong perempuan atau istri bergantung pada suami khususnya secara ekonomi dan membuat perempuan sepenuhnya berada bawah kuasa suami. Akibatnya istri sering diperlakukan semena-mena sesuai kehendak suami (Ciciek, 2005). Faktor lain yang mempengaruhi relasi kuasa pelaku kekerasan dalam rumah tangga yaitu pola relasi suami-istri. Pola relasi suami-istri sangat mempengaruhi peran antara suami dan istri serta pembagian kekuasaan. Scanzoni dan Scanzoni membagi hubungan suami-istri menjadi empat macam pola perkawinan yaitu; pola owner property, pola head complement, pola senior-junior, dan pola equal partner. Keempat pola ini dihasilkan dari kondisi sosial ekonomi yang khusus dan bersifat dinamis (Zahara, 2017). Pembagian kekuasaan yang sama dalam keluarga akan memiliki tingkat konflik, kontrol, dan kekerasan yang rendah (Antai, 2011).

Berdasarkan data awal yang didapatkan dari pidana kasus KDRT di Lapas klas II A Padang, ditemukan bahwa pelaku memiliki persepsi bias gender yang cukup tinggi. Adanya persepsi bias gender dan relasi suami istri yang tidak seimbang memungkinkan dapat meningkatkan resiko terjadinya kekerasan dalam rumah tangga. Rumusan masalah dalam penelitian ini adalah apa saja faktor-faktor yang mempengaruhi relasi kuasa pelaku kekerasan dalam rumah tangga? Tujuan dari penelitian ini adalah untuk menganalisis faktor-faktor yang mempengaruhi relasi kuasa pelaku kekerasan dalam rumah tangga (KDRT).

\section{METODOLOGI}

Penelitian ini dilakukan terhadap pelaku kekerasan dalam rumah tangga yang menjalani pidana di Lembaga Pemasyarakatan Klas II A Padang pada tanggal 15 Februari 2020 sampai dengan 26 Juli 2020. Penelitian ini dirancang menggunakan pendekatan kualitatif jenis deskriptif untuk memperoleh pemahaman tentang situasi dan makna terhadap subjek yang diteliti. Pemilihan subjek dalam penelitian ini menggunakan purposive sampling, sehingga didapatkan subjek satu orang narapidana kasus KDRT. Teknik pengumpulan data melalui observasi langsung terkait kegiatan di dalam Lapas, wawancara, dan analisis dokumen. Namun, untuk data awal peneliti memberikan angket kepada subjek untuk melihat persepsi bias gender pengambilan keputusan, dan pembagian kerja dalam rumah tangga subjek. Pengujian keabsahan data yaitu menggunakan triangulasi sumber. Analisis data dilakukan melalui tiga kegiatan, yaitu reduksi data, penyajian data, dan penarikan kesimpulan (Miles \& Huberman, 2008).

\section{HASIL DAN PEMBAHASAN \\ Deskripsi Informan WD}

Subjek berjenis kelamin pria dengan inisial WD berusia 46 tahun adalah warga binaan di Lapas Klas IIA Padang yang merupakan narapidana kasus KDRT dengan usia termuda dan masa tahanan paling lama dibandingkan pidana KDRT lainnya. WD memiliki postur badan yang sedikit berisi dengan tinggi sekitar $165 \mathrm{~cm}$, kulit sawo matang dan rambut sedikit ikal. Pekerjaan WD sebelumnya adalah tukang perabot yang membuka usaha sendiri di rumahnya, sedangkan istri WD bekerja sebagai petani. Tindakan pidana yang dilakukan WD ialah kekerasan fisik berupa memukul kepala istri menggunakan kayu balok hingga menyebabkan istri meninggal. Alasan dilakukannya kekerasan adalah pertengkaran verbal mengenai baju anak yang tidak terselesaikan hingga menyebabkan terjadinya kekerasan fisik. Tindakan ini menyebabkannya harus menjalani masa tahanan selama lima belas tahun dan menyerahkan hak asuh ketiga orang anaknya kepada keluarga istri.

\section{Pembahasan}

Hasil observasi yang diperoleh terhadap WD terkait kegiatan dan interaksi sosialnya di dalam Lapas, tidak terlihat relasi kuasa WD dalam berinteraksi sesama warga binaan. Peneliti melihat WD merupakan orang yang cukup tertutup dan tidak banyak berinteraksi sesama warga binaan maupun petugas. WD lebih banyak menghabiskan waktu di kamar dan terlihat tidak mengikuti kegiatan yang sudah difasilitasi di dalam Lapas, seperti kegiatan keagamaan, program santri, program kemandirian, pelatihan keterampilan, olahraga, dan sebagainya. 


\section{Analisis Faktor-faktor yang Mempengaruhi Relasi Kuasa Pelaku Kekerasan dalam Rumah Tangga (KDRT)}

\section{Persepsi Bias Gender}

Bias gender dapat dilihat melalui alokasi peran, hak, tanggungjawab, dan harapan yang diletakkan pada laki-laki maupun perempuan yang berlaku di masyarakat. Membahas mengenai bias gender tidak terlepas dari ketidaksetaraan gender yang dapat menimbulkan dampak terhadap diskriminasi gender terutama bagi perempuan. Jika seseorang memiliki kesadaran akan kesetaraan gender, maka tidak akan ada penilaian bahwa posisi dan peran lakilaki lebih tinggi dibandingkan perempuan serta memiliki kontrol dan dominasi terhadap perempuan Djojonegoro (Nurhayati, 2005) yang dapat berdampak pada diskriminasi gender hingga terjadinya kekerasan dalam rumah tangga. Persepsi bias gender di sini akan dilihat berdasarkan persepsi terkait marginalisasi, subordinasi, peran ganda, stereotip dan kekerasan berbasis gender (Fakih, 2008) dimana aspek-aspek ini mengandung unsur ketidaksetaraan gender terhadap perempuan. Berdasarkan data awal yang telah dikumpulkan, diperoleh persentase sebesar 4,3\% dari skor tertinggi sebesar 5\%. Semakin subjek setuju terhadap pernyataan yang disajikan maka persepsi terhadap bias gender semakin tinggi dan begitupula sebaliknya. Maka, hal ini menandakan bahwa WD memiliki persepsi bias gender yang cukup tinggi. Berikut akan dipaparkan data secara deskriptif.

\section{Marginalisasi}

Berdasarkan data yang diperoleh diketahui bahwa WD memiliki persepsi yang setuju jika pekerjaan yang dilakukan istri tidak penting apabila tidak menghasilkan uang. WD kerap melarang istri untuk mengikuti kegiatan di luar rumah. Namun, WD tidak melarang jika istri ingin bekerja untuk membantu memenuhi kebutuhan keluarga. WD juga memandang perempuan tidak bisa menjadi seorang pemimpin terutama dalam rumah tangga. Menurutnya, jika dalam suatu rumah tangga, suami yang menjadi pemimpin keluarga. Ijab kabul dipandang sebagai penyerahan istri dari mertua kepadanya, sehingga ia yang bertanggungjawab sepenuhnya terhadap istri. Istri kodratnya yaitu mengurus rumah tangga, anak, dan melayani suaminya, sehingga menurutnya istri harus patuh terhadapnya dalam segala hal.

\section{Subordinasi}

Berdasarkan data yang diperoleh diketahui bahwa WD setuju jika perempuan tidak boleh menduduki jabatan lebih tinggi daripada laki-laki karena kodrat perempuan di bawah laki-laki, kebutuhan suami dan rumah tangga lebih utama untuk dipenuhi dibandingkan dengan kebutuhan istri, kepentingannya harus lebih diprioritaskan dibandingkan istri dan perempuan seharusnya menerima gaji yang lebih kecil daripada laki-laki walaupun dalam pekerjaan yang sama. WD kerap memandang bahwa laki-laki memiliki pekerjaan yang begitu banyak dan tanggungjawab lebih berat. Sementara istri hanya bergantung dengan suaminya. Penghasilan istri yang didapatkannya dari bekerja dipandang tidak mampu memenuhi kebutuhan rumah tangga. Karena menurut WD, laki-laki yang dapat menjamin dan bertanggungjawab terhadap kehidupan rumah tangganya. Berdasarkan teori, subordinasi yaitu memandang satu gender lebih rendah dibandingkan yang lain (Fakih, 2008). Persepsi WD terkait subordinasi perempuan diketahui tidak hanya pada sektor domestik tetapi juga berkaitan dengan sektor publik. Budaya telah mendudukan laki-laki sebagai superior dan perempuan sebagai inferior. Laki-laki yang telah dibentuk memiliki kuasa, mengarahkan pengetahuan masyarakat (Foucault \& Couteau Jean, 1997), sehingga adanya hubungan antar jenis kelamin dibentuk dengan dominasi subordinasi yang mengakibatkan perempuan diposisikan sebagai pihak yang di atur laki-laki

\section{Peran Ganda}

Terdapatnya persepsi peran ganda pada subjek WD. Dimana istri yang bekerja di sawah, juga tetap dipandang harus melaksanakan kodratnya sebagai ibu rumah tangga, mengurus anak dan melayani suaminya. Tidak adanya pembagian kerja di sektor domestik yang dilakukan. Istri bahkan juga dipandang harus menggantikan peran dan tanggungjawabnya ketika WD sedang tidak berada di rumah. Sehingga terdapatnya beban pekerjaan yang diterima istri lebih banyak dibandingkan suami. WD memiliki persepsi yang setuju terhadap peran ganda. Meskipun istri bekerja di wilayah publik namun tidak disertai dengan berkurangnya beban di wilayah domestik. Setelah bekerja di sektor publik, tanggungjawab domestik tetap menjadi kewajiban dan tanggungjawab istri (Fakih, 2008). Perempuan dinilai memiliki tugas dan 
tanggung jawab yang berat dan terus menerus. Perempuan selain melayani suami, hamil, melahirkan, menyusui, menjaga rumah serta juga ikut mencari nafkah. Namun hal ini tidak berarti menghilangkan tugas dan tanggung jawabnya di sektor domestik. Tanggung jawab domestik masih tetap berada di pundak perempuan. Akibatnya mereka mengalami beban yang berlipat ganda.

\section{Stereotip}

Berdasarkan data yang diperoleh diketahui bahwa WD setuju jika seharusnya perempuan bersifat pemalu, cengeng, tidak mandiri, dan secara fisik lebih lemah dibanding laki-laki. Menurutnya perempuan seharusnya bersikap baik, sholeha, taat terhadap agama, adapun laki-laki bersifat tegas dan pemberani. Istri ketika sudah menikah bertanggung jawab mengurus anak, rumah tangga dan melayani suaminya, sedangkan suami hanya bertanggungjawab atas perekonomian keluarga. sehingga istri dipandang bergantung pada suami dan suami bertanggungjawab terhadap istrinya. Stereotip adalah kesepakatan antara suatu kelompok terhadap gambaran kelompok lainnya dengan kecenderungan menampilkan gambaran atau gagasan yang keliru (Sobur, 2009). Sehingga stereotip juga menunjukkan adanya relasi kekuasaan yang timpang atau tidak seimbang yang bertujuan untuk menaklukkan atau menguasai pihak lain. Pelabelan negatif sering dilakukan atas dasar anggapan gender ini. Seringkalinya pelabelan negatif ditimpakan kepada perempuan. Anggapan bahwa perempuan menyandang label lemah dan laki-laki kuat sehingga memandang perempuan selalu bergantung pada laki-laki dan peran perempuan dipinggirkan.

\section{Kekerasan}

Berdasarkan data yang diperoleh diketahui bahwa WD cenderung memiliki persetujuan terhadap kekerasan, dimana ia setuju bahwa suami tetap layak menjadi pemimpin rumah tangga sekalipun tidak memenuhi kewajiban memberi nafkah istri, istri harus melayani secara seksual kapanpun ia mau, cerai ataupun talak merupakan haknya sepenuhnya, dan ia juga merasa berhak memarahi, menghardik, dan berkata kasar kepada istri dimanapun jika istrinya berbuat salah. Kekerasan dapat menyebabkan kerusakan pada fungsi psikologis (Putra, 2020). Undang-Undang No. 23 Tahun 2004 telah mengemukakan bahwa tindak kekerasan terhadap istri dalam rumah tangga terbagi ke dalam empat macam, yaitu: (1) kekerasan fisik, yang mengakibatkan rasa sakit, jatuh sakit, atau luka (2) kekerasan psikis, dapat berupa menghina, memaki, membentak, dsb (3) kekerasan seksual, berupa pemaksaan hubungan seksual dan (4) penelantaran anggota rumah tangga, yaitu tidak diberi nafkah secara rutin atau dalarn jumlah yang cukup, membatasi atau melarang untuk bekerja yang layak di dalam atau di luar rumah, sehingga korban di bawah kendati orang tersebut (Undang-Undang Republik Indonesia Nomor 23 Tahun 2004 tentang Penghapusan Kekerasan dalam Rumah Tangga, 2004). Sehingga berdasarkan Undang-Undang tersebut dapat diketahui bahwa, kekerasan pada pandangan subjek di sini tidak hanya berupa kekerasan psikis, namun juga kekerasan seksual dan kekerasan ekonomi atau penelantaran.

\section{Kepribadian Agresif}

Penemuan dalam penelitian ini lebih lanjut menunjukkan kontrol diri yang buruk pada WD, dilihat dari sikapnya yang mudah emosional pada istri dan juga anaknya, terutama terhadap anak pertamanya. Anak pertamanya sering menerima tindakan kekerasan dari WD berupa pukulan ataupun dimasukkan ke dalam kolam. Tindakan yang diterima anaknya ini hanya dikarenakan permasalahan perkelahian kecil antara ia dengan adiknya. Begitupula dengan istri, dimana istri sering menerima perlakuan kasar dari WD berupa perkataan kasar hingga pada agresi fisik berupa pukulan, tendangan dan tamparan dikarenakan persoalan rumah tangga seperti anak, makan, sambal, pemintaan bantuan dari istri, dan persoalan ringan lainnya. Kontrol diri yang buruk pada WD ini ditunjukkan oleh sikapnya yang mudah marah hingga pada agresi verbal bahkan fisik dalam menghadapi berbagai persoalan. Untuk persetujuan terhadap kekerasan sendiri, pada data angket awal WD memang kerap setuju untuk menghardik, memaki dan berkata kasar jika istri melakukankesalahan. Namun untuk kekerasan fisik hanya cenderung ketika istri melakukan kesalahan yang fatal baginya.

Agresi didefinisikan sebagai permusuhan, kemarahan, dan lekas marah sehingga sering terlibat pada agresi verbal dan fisik. Sehingga subjek yang memilki kepribadian agresi menyebabkannya mudah marah hingga pada tindakan atau perlakuan kekerasan verbal dan fisik. Anderson \& Bushman (2002) mendefinisikan agresi sebagai tindakan terhadap individu lain yang merugikan dan dapat menyebabkan kerusakan. Kerusakan dapat terjadi dalam bentuk 
psikis maupun fisik. Agresi fisik melanggar norma dan menyebabkan kerusakan fisik (Stets, 1990), seperti halnya tindakan memukul, menendang, menampar, menusuk yang dilakukan oleh WD. Sedangkan agresi verbal mengacu pada tindakan seperti ucapan yang menyakitkan atau mengancam (Stets, 1990). Namun, meskipun tindakan agresif tidak mengakibatkan rasa sakit dan cedera fisik, namun dapat menyebabkan cedera psikologis yang tidak tampak (Stubbs \& Dickens, 2009).

Penelitian oleh Gündoğdu, Yavuzer, \& Karataş (2018) menunjukkan bahwa agresi laki-laki menjadi lebih tinggi dikarenakan peran sosial yang melekat pada laki-laki dan perempuan. Sehingga kepercayaan terhadap perbedaan gender tersebut menjadi prediktor terjadinya agresi verbal dan fisik dalam rumah tangga. Seseorang yang agresi akan merasakan sensitivitas yang lebih tinggi terhadap pasangan atau anak sehingga menyebabkan kemarahan yang lebih besar terhadap anggota keluarga (Wilkowski \& Robinson, 2008). Agresif menyebabkan ketidakstabilan dan kualitas pernikahan, dimana seseorang yang memiliki kepribadian agresi mudah marah ketika segala sesuatu tidak sejalan dengan keinginannya (Goldscheid \& Liebowitz, 2015). Sehingga hal ini memberikan pembenaran untuk laki-laki agresi terhadap perempuan.

\section{Kecenderungan Memiliki Karakteristik Kepribadian Antisosial}

Pada subjek WD, ditemukan beberapa karakteristik kepribadian antisosial, meliputi rasa empati yang rendah serta pelanggaran terhadap norma sosial, pola perilaku agresif, berhadapan dengan tindakan kriminal, dan egosentrisitas (Barlow, David H. \& Durand, 2011).

\section{Rasa empati yang rendah serta pelanggaran terhadap norma sosial.}

Rasa empati subjek yang rendah ditunjukkan dari perilakunya yang kerap tidak peduli dengan sekitarnya. WD tetap memutar musik dan mesin kerja ketika tetangga sedang kemalangan bahkan meminta upah kerja terhadap istri dan saudaranya. Semua yang dikerjakannya harus dibayar. Istri hanya diberikan nafkah yang sedikit dan tidak mencukupi kebutuhan keluarga menyebabkan istrinya harus bekerja. Istri bekerja di sawah, namun istri juga dilimpahkan tanggungjawab anak sepenuhnya olehnya. Tidak adanya pembagian kerja yang adil di sektor domestik. Bahkan istri sulit untuk meminta bantuan WD baik pada pekerjaan sawah maupun perkerjaan rumah. Selain itu, WD juga tidak memberikan hak yang sama terhadap anaknya. WD bersikap tidak peduli dan cenderung melakukan diskriminasi terhadap anak pertamanya, yang ditunjukkan dengan memberikan kasih sayang, perhatian dan perlakuan berbeda antara anak pertama dan adik-adiknya. Hal ini menunjukkan WD tidak hanya memiliki empati yang rendah tetapi juga dibeberapa keadaan adanya pengabaian terhadap norma sosial. Seseorang dengan kepribadian antisosial memiliki sikap empati yang rendah bahkan pelanggaran terhadap norma sosial (Semiun, 2006).

\section{Pola perilaku agresif}

WD memiliki kontrol diri yang buruk ditunjukkan oleh sikap emosional berupa mudah marah hingga pada agresi verbal bahkan fisik dalam menghadapi berbagai persoalan sekalipun persoalan ringan. Faktor yang menyebabkan munculnya sikap emosional WD dapat berupa permasalahan makan, anak, dirinya yang tidak ingin membantu istri dan permasalahan lainnya, hingga menyebabkan perdebatan verbal yang memunculkan perkataan kasar sampai pada kekerasan fisik seperti memukul, menampar, dan menendang. Sikap agresi yang ditunjukkan tidak hanya terhadap istri dan anak tetapi juga terhadap adik istri. Hal tersebut sesuai dengan pemaparan Rakovec-Felser (2014) bahwa laki-laki antisosial umumnya agresif terhadap orang lain dan pasangannya, berbeda dengan perempuan antisosial yang cenderung agresif hanya terhadap pasangannya.

\section{Berhadapan dengan tindakan kriminal}

Perlakuan WD yang mengarah pada tindakan kriminalitas sudah dilakukannya lebih dari sekali.Tindakan yang dilakukannya berupa menutup mulut istri dengan menggunakan bantal, menarik lemari besar sehingga hampir terjatuh dan mnimpa ketiga orang anaknya yang saat itu masih kecil, dan terakhir adalah tindakan memukul istri menggunakan kayu hingga meninggal yang menyebabkannya harus menjalani masa tahanan selama 15 tahun. Berdasarkan teori yang ditemukan, diketahui bahwa antara kriminalitas dan perilaku antisosial memiliki hubungan yang kuat. Adapun beberapa dari orang antisosial cenderung melakukan aktifitas kriminal seperti melakukan KDRT, membunuh, dan sebagainya tanpa diikuti dengan rasa bersalah setelah mereka melakukan tindakan tersebut (Santoso, Krisnani, \& Isna Deraputri, 2017). 
Karena hal tersebut, menyebabkan seseorang dengan gangguan antisosial berhubungan dengan perilaku tindakan kriminal dan mendekap di Lapas. Meskipun terdapat juga dari mereka antisosial yang taat hukum, namun tetap memiliki sikap kejam serta tidak menghargai minat dan perasaan orang lain (Semiun, 2006). Pelaku umumnya memiliki rasa empati yang rendah sehingga menyebabkan mereka tidak memiliki penyesalan atas tindakan yang mereka lakukan pada korban (Loseke, Gelles, \& Cavanaugh, 2005).

\section{Egosentrisitas}

Perlakuan WD dipandang egosentris terlihat dari sikapnya yang sibuk dengan dirinya dan tidak peduli dengan sekitar. Ketika mendapatkan penghasilan dari pekerjannya, ia lebih banyak menggunakan uang untuk dirinya. Nafkah yang diberikan kepada istri dengan jumlah sedikit dan tidak mencukupi untuk memenuhi kebutuhan rumah tangga sehari-hari. Sehingga untuk pemenuhan kebutuhan keluarga, istri yang harus mendapatkan penghasilan dari bekerja di sawah. Bahkan untuk membeli rumah biayanya juga ditanggung oleh istri. Adapun selain istrinya bekerja, istri juga yang bertanggung jawab dalam mengurus rumah dan anak. Sedangkan WD tidak peduli. Pengambilan keputusan kerap berada padanya. Istri harus menerima keputusannya dan tidak boleh untuk membantahnya ataupun memeberikan masukan kepada. Selain itu, segala yang dilakukannya, seringkali diminta bayarannya. Ia tidak mau bekerja cuma-cuma untuk orang lain. Bahkan sepetak kayu sisa pekerjaannya pun ia tetap tidak ingin memberikannya kepada orang lain. Sehingga dibeberapa kondisi, WD menampakkan perilaku yang dinilai pelit. Di Lapas, WD juga dikenal tertutup. Di beberapa waktu, ia juga tampak tidak mengikuti kegiatan apapun dan lebih banyak menghabiskan waktu di kamarnya. Sedangkan dari pagi hingga sore hari para wargabinaan lainnya tampak melakukan berbagai aktifitas yang telah disediakan di Lapas, seperti kegiatan keagamaan, olah raga, kemandirian, bercengkrama di teras kamar, menerima kunjungan dan lainnya. Namun ia tidak terlihat keluar dari kamarnyau. Berdasarkan teori, ditemukan bahwa seseorang dengan kepribadian antisosial umumnya berpusat pada diri sendiri, mengharuskan orang lain bersikap sesuai dengan cara yang diinginkannya, selalu merasa dirinya benar dan pengabaian terhadap orang lain (Barlow, David H. \& Durand, 2011). Sehingga hal ini menyebabkan WD sulit untuk berinteraksi sosial. Sikap mengharuskan orang lain bertindak sesuai dengan cara yang diinginkan menyebabkannya sering marah hingga melakukan kekerasa kepada istri dan juga anaknya ketika perkataannya dibantah atau tindakan mereka tidak sesuai dengan yang diinginkan WD. Orang antisosial dapat bertengkar ketika sesuatu tidak berjalan sesuai dengan cara mereka. Selalu merasa dirinya benar dan melakukan pengabaian terhadap orang lain. Hal ini tergambarkan pada perilaku WD yang sering bertindak sesukanya serta mengabaikan tanggungjawabnya terhadap istri dan anaknya. Terkait kepribadian antisosial, Millon \& Davis (Santoso et al., 2017) membagi kepribadian antisosial menjadi lima variasi, yaitu antisosial penjaga reputasi, antisosial nomadis, antisosial pencemburu/ iri, antisosial pengambil resiko, dan antisosial pendengki. Adapun berdasarkan hasil temuan, diketahui terdapat beberapa karakteristik WD yang teridentifikasi menunjukkan variasi antisosial pencemburu/iri dengan karakteristik meliputi sifat yang serakah, selalu merasa kekurangan tergambarkan melalui sikapnya yang tetap meminta bayaran terhadap keluarga akan setiap pekerjaan yang dilakukannya untuk mereka. Selalu ingin mendapatkan dibandingkan memberi tergambarkan pada sikapnya yang hanya memberi nafkah istri sedikit sedangkan ia bekerja terus menerus dengan penghasilan yang tidak diketahui digunakan untuk apa. Seseorang dengan gangguan penyakit kepribadian antisosial cenderung terlihat normal dan baik dalam masyarakat. Mereka kurang dapat mengontrol rasa empati, terkesan tidak perduli dengan perasaan orang-orang disekitar mereka dan mereka mencari kebenaran dari apa yang telah mereka lakukan meskipun itu tidak sesuai dengan nilai-nilai yang ada (Semiun, 2006).

\section{SIMPULAN DAN SARAN}

Dari data yang telah di dapatkan, ditemukan faktor-faktor yang mempengaruhi relasi kuasa subjek pelaku kekerasan dalam rumah tangga yaitu sebagai berikut; (1) Terdapatnya persepsi subjek yang bias gender terkait marginalisasi, subordinasi, stereotip, peran ganda, dan kekerasan seperti menganggap peran dan tanggungjawab utama perempuan adalah pada sektor domestik sehingga adanya ketidakadilan pembagian kerja pada sektor domestik menyebabkan munculnya double burden yang harus diemban istri, suami adalah pemimpin dalam rumah tangga yang kedudukannya tidak bisa digantikan istri dan istri adalah tanggungjawab suami sepenuhnya (2) kepribadian agresif yang lebih tinggi dipandang berada pada laki-laki. Pandangan ini berkaitan dengan peran sosial yang melekat pada laki-laki dan perempuan. Sehingga dengan adanya 
pandangan sifat agresif lebih tinggi berada pada laki-laki, menyebabkan mereka merasa wajar untuk berperilaku agresi baik fisik maupun verbal. Subjek yang memilki kepribadian agresif, menyebabkannya mudah marah dengan disertai pada agresi verbal dan fisik. Seperti menghardik, mencaci dan berkata kasar yang terkadang disertai dengan perlakuan menampar, menendang, dan memukul (3) subjek yang memiliki karakteristik kepribadian antisosial berhubungan dengan kecenderungan untuk melakukan aktifitas kriminal seperti KDRT tanpa diikuti perasaan bersalah terhadap tindakan yang dilakukannya.

Maka dari itu, Konselor diharapkan dapat memberikan intervensi psikologis melalui layanan bimbingan dan konseling berbasis masyarakat dan bagi lembaga pemasyarakatan, dirasakan perlu juga untuk lembaga memfasilitasi program konseling khususnya bagi pelaku KDRT dengan tujuan untuk mendidik dan menyadarkan pelaku bahwa perbuatannya adalah tindakan kejahatan.

\section{DAFTAR RUJUKAN}

Afdal. (2015). Pemanfaatan konseling keluarga eksperensial untuk penyelesaian kasus kekerasan dalam rumah tangga. Jurnal Pendidikan Indonesia, 1(1), 76-79.

Anderson, C. A., \& Bushman, B. J. (2002). Human aggression. Annual Review of Psychology, 53(1), 27-51.

Antai, D. (2011). Controlling behavior, power relations within intimate relationships and intimate partner physical and sexual violence against women in Nigeria. BMC Public Health, 11(1), 1-11. https://doi.org/10.1186/1471-2458-11-511

Asmarany, A. I. (2007). Bias gender sebagai prediktor kekerasan dalam rumah tangga. Jurnal Psikologi, 35(1), 1-20.

Asnawi, H. S. (2011). HAM dalam ruang domestik: Studi terhadap UU. No. 23 tahun 2004 tentang PDKRT. Al-Mawarid, 11(2), 195-210.

Barlow, David H. \& Durand, V. M. (2011). Abnormal psychology: An integrative approach. Canada: Nelson Education.

Chrysos, E. S., Taft, C. T., King, L. A., \& King, D. W. (2005). Gender, partner violence, and perceived family functioning among a sample of Vietnam veterans. Violence and Victims, $20(5), 549$.

Ciciek, F. (2005). Jangan ada lagi kekerasan: Ikhtiar mengatasi kekerasan dalam rumah tangga, belajar dari kehidupan Rasulullah SAW. Jakarta: Gramedia Pustaka Utama: LKAJ : Asia Foundation.

Fakih, M. (2008). Analisis gender dan transformasi sosial. Yogyakarta: Insist Press.

Foucault, M., \& Couteau Jean, E. (1997). Sejarah seksualitas: Seks dan kekuasaan. Jakarta: PT. Gramedia Pustaka Utama.

Gage, A. J., \& Hutchinson, P. L. (2006). Power, control, and intimate partner sexual violence in Haiti. Archives of Sexual Behavior, 35(1), 11-24.

Garcia, C. B., \& Schneider, L. (2017). Systemic approach in Latino Families surviving domestic violence in the United States of America. Journal of Educational Psychology, 5(2), 299319. https://doi.org/http://dx.doi.org/10.20511/pyr2017.v5n2.164

Goldscheid, J., \& Liebowitz, D. J. (2015). Due diligence and gender violence: parsing its power and its perils. Cornell Int'l LJ, 48, 301.

Gündoğdu, R., Yavuzer, Y., \& Karataş, Z. (2018). Irrational beliefs in romantic relationships as the predictor of aggression in emerging adulthood. Journal of Education and Training Studies, 6(3), 108-115.

Harnoko, B. R. (2010). Dibalik tindak kekerasan terhadap perempuan. Muwazah, 2(1), 181-188.

Komnas Perempuan. (2019). Catatan tahunan tentang kekerasan terhadap perempuan. Retrieved August 21, 2019, from https://www.komnasperempuan.go.id/reads-catatan-tahunankekerasan-terhadap-perempuan-2019

Loseke, D. R., Gelles, R. J., \& Cavanaugh, M. M. (2005). Current controversies on family violence. Sage.

Manumpahi, E., Goni, S., \& Pongoh, H. W. (2016). Kajian kekerasan dalam rumah tangga terhadap psikologi anak di Desa Soakonora Kecamatan Jailolo Kabupaten Halmahera Barat. E-Journal Acta Diurna, 5(1).

Miles, M. B., \& Huberman, A. M. (2008). Metodologi penelitian kuantitatif dan kualitatif dan $R \& D$. Bandung: Alfabeta.

Mufidah. (2008). Psikologi keluarga Islam: Berwawasan gender. Malang: UIN Maliki Press.

Muljono, P. (2015). Analisis perbandingan KDRT oleh suami dan istri di Jawa Barat, 31(2), 271282.

Nurhayati, S. R. (2005). Atribusi kekerasan dalam rumah tangga, kesadaran terhadap kesetaraan 
gender, dan strategi menghadapi masalah pada perempuan korban kekerasan dalam rumah tangga. Universitas Gajah Mada.

Pasalbessy, J. D. (2010). Dampak tindak kekerasan terhadap perempuan dan anak serta solusinya. Jurnal Sasi, 16(3).

Peraturan Mahkamah Agung Republik Indonesia Nomor 3 Tahun 2017 tentang pedoman mengadili perkara perempuan berhadapan dengan hukum (2017).

Putra, B. N. (2020). Marital Satisfaction : An Analysis of Long Distance Marriage Couples, 4(1), 64-69. https://doi.org/10.24036/00287za0002

Rakovec-Felser, Z. (2014). Domestic violence and abuse in intimate relationship from public health perspective. Health Psychology Research, 2(3), 1821. https://doi.org/10.4081/hpr.2014.1821

Santoso, M. B., Krisnani, H., \& Isna Deraputri, G. N. (2017). Gangguan kepribadian antisosial pada narapidana. Share: Social Work Journal, 7(2), 18-27. https://doi.org/10.24198/share.v7i2.15681

Sari, P. F., \& Afdal. (2020). Forgiveness analysis of domestic violence victims in Aceh. International Journal of Research in Counseling and Education, 4(2), 131-138. https://doi.org/10.24036/00314za0002

Semiun, Y. O. F. M. (2006). Kesehatan mental 2. Yogyakarta: Kanisius.

Sobur, A. (2009). Psikologi umum. Bandung: CV Pustaka Setia.

Soeroso, M. H. (2010). Kekerasan dalam rumah tangga dalam perspektif yuridis-viktimologis. Jakarta: Sinar Grafika.

Sofiani, T. (2008). Tafsir agama dan kekerasan berbasis gender. Jurnal Penelitian, 5(2), 1-14.

Stets, J. E. (1990). Verbal and physical aggression in marriage. Journal of Marriage and the Family, 501-514.

Stubbs, B., \& Dickens, G. (2009). Physical assault by patients against physiotherapists working in mental health settings. Physiotherapy, 95(3), 170-175.

Undang-Undang Republik Indonesia Nomor 23 Tahun 2004 tentang Penghapusan Kekerasan dalam Rumah Tangga (2004).

Vyas, S., \& Jansen, H. A. F. M. (2018). Unequal power relations and partner violence against women in Tanzania: A cross-sectional analysis. BMC Women's Health, 18(1), 185.

WHO. (2013). Prevalence and health effects of intimate partner violence and non-partner sexual violence. South African. Retrieved from https://www.who.int/reproductivehealth/publications/violence/9789241564625/en/

Wilkowski, B. M., \& Robinson, M. D. (2008). The cognitive basis of trait anger and reactive aggression: An integrative analysis. Personality and Social Psychology Review, 12(1), 3-21.

Witte, T. H., Schroeder, D. A., \& Lohr, J. M. (2006). Blame for intimate partner violence: An attributional analysis. Journal of Social and Clinical Psychology, 25(6), 647-667.

Ybarra, G. J., Wilkens, S. L., \& Lieberman, A. F. (2007). The influence of domestic violence on preschooler behavior and functioning. Journal of Family Violence, 22(1), 33-42.

Zahara, R. A. (2017). Potret relasi suami-istri: Masyarakat petani dalam mewujudkan fungsi keluarga (studi di Desa Kayen Kidul Kecamatan Kayen Kidul Kabupaten Kediri), 28(1), 123-146.

Zikra, Z. (2019). Chronotherapy for women victims of domestic violence. JPPI (Jurnal Penelitian Pendidikan Indonesia), 5(1), 20-23. 